\title{
THE ACCURACY OF 99MTC-DTPA SCINTIGRAPHY IN THE EVALUATION OF ACUTE RENAL GRAFT COMPLICATIONS
}

\author{
ADELINA SANCHES, ELBA C.S.C. ETCHEBEHERE, MARILDA MAZZALI, G. ALVES \\ FILHO, MARIANA C.L. LIMA, ALLAN O. SANTOS, CELSO D. RAMOS, IZILDA \\ CARDINALLI, ATHANASE BILLIS, EDWALDO E. CAMARGO \\ Division of Nuclear Medicine, Department of Radiology, and Division of Nephrology, Department of \\ Internal Medicine, and Department of Pathology, Campinas State University, UNICAMP, Campinas, \\ São Paulo, Brazil
}

\begin{abstract}
Purpose: Renal scintigraphy has been used for many years in the evaluation of renal transplants and can help in the diagnosis of graft complications, leading to prompt clinical management and preventing further deterioration of renal function. The purpose of this study was to evaluate the overall accuracy of renal scintigraphy with ${ }^{99 \mathrm{~m}} \mathrm{Tc}-\mathrm{DTPA}$ in the diagnosis of acute renal graft complications.

Materials and Methods: Seventy-six scintigraphic studies performed in 55 patients (ages ranging from 6 to 65 years), were reviewed. Scintigraphy results were compared to biopsies performed within 5 days of imaging. ${ }^{99 \mathrm{~m}} \mathrm{Tc}-\mathrm{DTPA}$ study was performed within a mean time of 19 days after kidney transplants. Dynamic images were performed in the anterior position of the abdomen and pelvis every 2 seconds for 80 seconds (flow phase) and every 15 seconds for 30 minutes (functional phase), after an intravenous injection of $370 \mathrm{MBq}(10 \mathrm{mCi})$ of ${ }^{99 \mathrm{~m}} \mathrm{Tc}-\mathrm{DTPA}$.

Results: The scintigraphic results were concordant with the biopsies in $86 \%$ of the cases studied. The sensitivities of renal scintigraphy for detection of acute tubular necrosis (ATN), acute rejection (AR) and cortical necrosis (CN) were $98 \%, 87 \%$ and $100 \%$, respectively. Specificities and accuracies for detection of ATN, AR and CN were $89 \%, 86 \%$ and $100 \%$, and $95 \%, 87 \%$ and $100 \%$, respectively.

Conclusion: Renal scintigraphy with ${ }^{99 \mathrm{~m} T c-D T P A}$ showed a good overall accuracy in the detection of acute renal graft complications. It can be used as a reliable tool in the routine evaluation of these patients.
\end{abstract}

Key words: kidney; kidney transplantation; radionuclide imaging; graft rejection; diagnosis

Int Braz J Urol. 2003; 29: 507-516

\section{INTRODUCTION}

Renal scintigraphy is one of the most frequently used methods in the evaluation of renal allograft dysfunction (1-4) along with other diagnostic tests, such as clinical criteria, ultrasound, serum creatinine levels, fine needle aspiration biopsy, magnetic resonance imaging and core biopsy, helping in the identification of acute and long term complications (5-7). The most common renal transplant complications are acute tubular necrosis, rejection (hyperacute, accelerated, acute, chronic), cyclosporin toxicity, urine leak, hematoma, obstruction, lymphocele and renal artery stenosis.

Nuclear medicine plays an important role in the investigation of renal graft complications and several radiopharmaceuticals can be employed (8). Routinely, ${ }^{99 \mathrm{~m}} \mathrm{Tc}-\mathrm{DTPA}$ and ${ }^{99 \mathrm{~m}} \mathrm{Tc}-\mathrm{MAG}_{3}$ are used, although studies with ${ }^{131} \mathrm{I}-\mathrm{OIH},{ }^{99 \mathrm{~m}} \mathrm{Tc}-\mathrm{GHA}, \mathrm{Ga}-67$, ${ }^{99 \mathrm{~m}} \mathrm{Tc}$-sulfur colloid, radiolabeled leukocytes and platelets have also been performed (9-11). The scintigraphic evaluation of the transplanted kidney in- 
volves qualitative or quantitative analysis of the 3 phases of renal scintigraphy: the flow phase, the functional phase and the excretion phase $(4,12)$. ${ }^{99 \mathrm{~m}} \mathrm{Tc}-$ DTPA can be very helpful in the evaluation of dysfunctional kidneys, since it has a reasonable extraction rate and a low cost.

Biopsy, the gold standard for the detection of renal graft non-surgical complications, is an invasive procedure that carries a higher morbidity when compared to non-invasive diagnostic tests such as renal scintigraphy. Ideally, its use should be restricted to patients in whom non-invasive procedures are indeterminate.

The purpose of this study was to determine the accuracy of dynamic renal scintigraphy with ${ }^{99 \mathrm{~m}} \mathrm{Tc}-$ DTPA in the identification of acute renal graft complications, when compared to core biopsy.

\section{MATERIALS AND METHODS}

\section{Patient Selection}

Seventy-six scintigraphic studies performed in 55 patients were reviewed. ${ }^{99 \mathrm{~m}} \mathrm{Tc}-\mathrm{DTPA}$ study was performed 1 day to a maximum of 6 months (mean 19 days) after kidney transplants (cadaveric or living donors).

Patients' ages ranged from 6 to 65 years (mean 37 years), 38 were males (69\%) and 49 (89\%) were recipients from cadaveric donors.

As part of the approach to transplanted patients in our medical institution, they would undergo renal scintigraphy routinely within the first 24 hours after surgery as a baseline study. Studies were repeated whenever complications were suspected, so as biopsies did, whenever clinically indicated. All patients in this study were retrospectively collected when performed ${ }^{99 \mathrm{~m}} \mathrm{Tc}-$ DTPA scintigraphy and core biopsies within a maximum time interval of 5 days between the two procedures.

Other diagnostic methods such as urinary outflow, creatinine levels, and Doppler ultrasound were performed whenever necessary but not taken into analysis since it is not the aim of the present study.

\section{Renal Scintigraphic Studies}

Patients received an intravenous injection of $370 \mathrm{MBq}(10 \mathrm{mCi})$ of ${ }^{99 \mathrm{~m}} \mathrm{Tc}-\mathrm{DTPA}$ and sequential images in the anterior position of the abdomen and pelvis, every 2 seconds for 80 seconds (flow phase) and every 15 seconds for 30 minutes (functional phase) were begun immediately after injection.

Additional hydration prior to the study was not addressed in the early days after transplantation since we did not want to interfere in the water balance of the patients. Later, as long as no restrictions advised by the referring physician, oral hydration with 500 to $600 \mathrm{ml}$ of water was given 30 minutes before the study.

Images were obtained on a camera-computer system equipped with a LEAP collimator.

The flow and functional phases were analyzed visually. Time-activity curves were also obtained from regions of interest (ROI) drawn over the grafted kidney and the aorta, subtracting the background activity.

\section{Imaging Interpretation}

Three experienced nuclear medicine physicians blindly interpreted the scintigraphies. Scintigraphic criteria were pre-established and then compared to the biopsy findings.

The blood flow phase was analyzed predominantly qualitatively using the aorta or the iliac arteries as references. Renal graft blood flow was considered normal when the peak kidney activity, within 6 seconds of the peak aorta or iliac activity, was equal to or higher than that of the peak aorta or iliac artery activity. Mildly, moderately and severely decreased flow was considered as so according to the severity of the flow reduction on the visual analysis as well.

Interpretation of the functional phase was also performed qualitatively, evaluating the images and quantitatively, evaluating the renogram curves. This evaluation included the accumulation phase, in which the extraction of the tracer from the blood during the first 3 minutes was evaluated; the concentration phase, in which the capacity of concentrating urine (water 
absorption) was analyzed; and the excretion phase, in which the transit of the radiopharmaceutical from the collecting system to the bladder was evaluated.

According to the scintigraphic findings in the flow and functional phases, the studies were classified as probable acute tubular necrosis (ATN), acute rejection (AR), cortical necrosis (CN), cyclosporin toxicity (CyT) and the association of ATN with AR (ATN + AR).

\section{Scintigraphic Criteria}

ATN - Normal or mildly decreased blood flow; normal or mildly decreased accumulation of the tracer, with a more prominent impairment of the concentration and excretion phases (difficulty in progression of the tracer in the damaged tubules) (Figure-1).

AR - Moderately or severely decreased blood flow and function or significantly decreased renal blood flow and function when compared to a previous study if available (Figure-2).
CN - Absence of blood flow and function, the location of the graft depicted as a photopenic area (Figure-3).

CyT - Scintigraphic pattern similar to ATN. Usually occurs after 30 days after the introduction of the drug, a period during which the impairment in renal function caused by ATN is expected to have subsided.

ATN + AR - Decreased flow and function in the follow up studies of patients with previously detected ATN.

\section{Histopathological Analysis}

Core biopsy specimens were reviewed by an experienced pathologist according to the Banff 97 criteria (13), using a $0-3+$ semi quantitative scale for each of the following histopathologic findings: acute glomerulitis, lymphocytic tubulitis, interstitial inflammation, vasculitis, chronic transplant glomerulopathy, interstitial fibrosis, tubular atrophy, and fibrointimal thickening. Evidence for possible
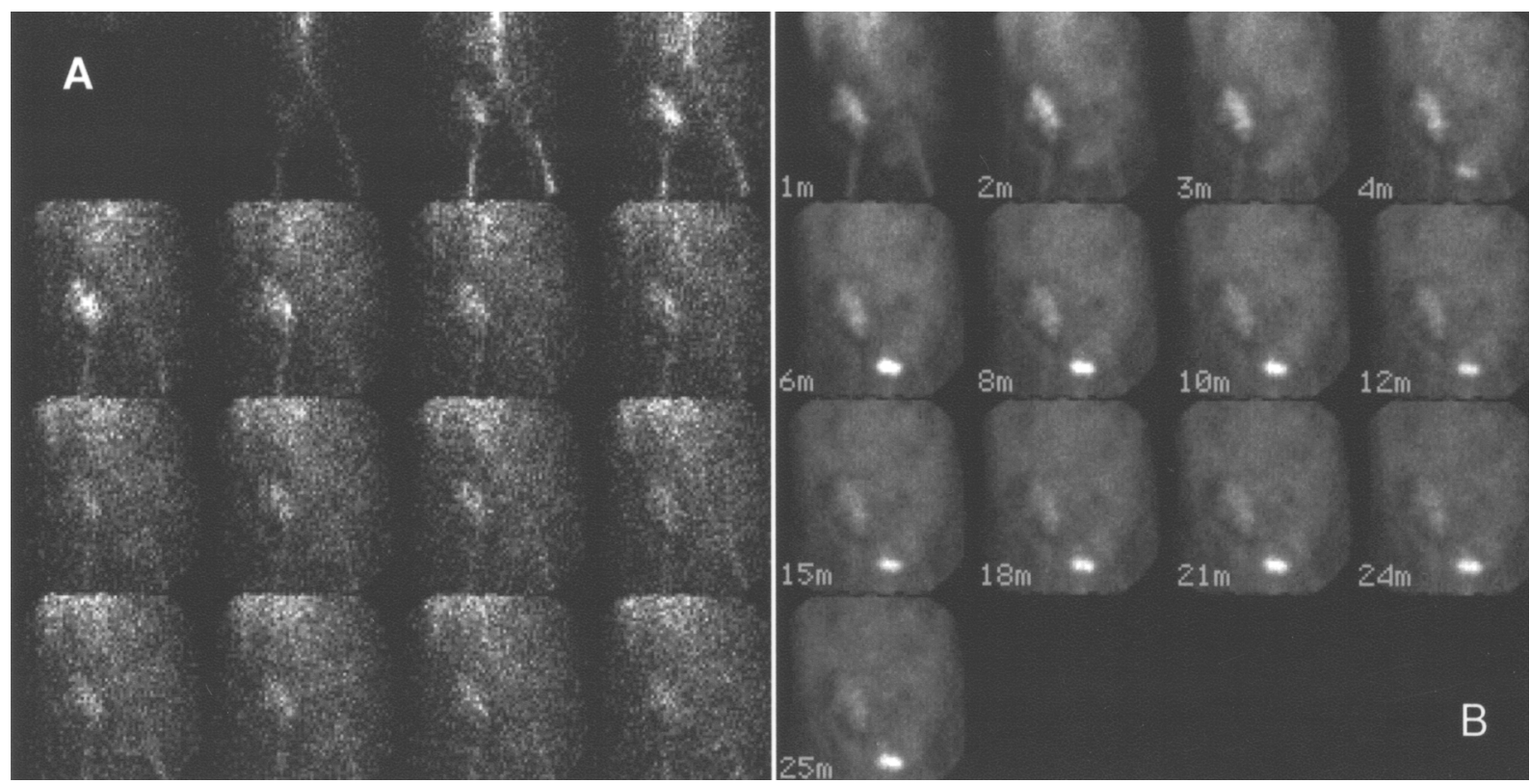

Figure 1 - Renal scintigraphic study with ${ }^{99 m}$ Tc-DTPA of a patient with acute tubular necrosis. A) Flow phase. Note the normal flow to the graft. B) Functional phase. There is mildly reduced accumulation of the radiotracer and moderate reduction of the concentration and excretion of the radiopharmaceutical. A rim of reduced radioactivity is noted, peripheral to the kidney, mainly on its lateral border and is due to an hematoma. 

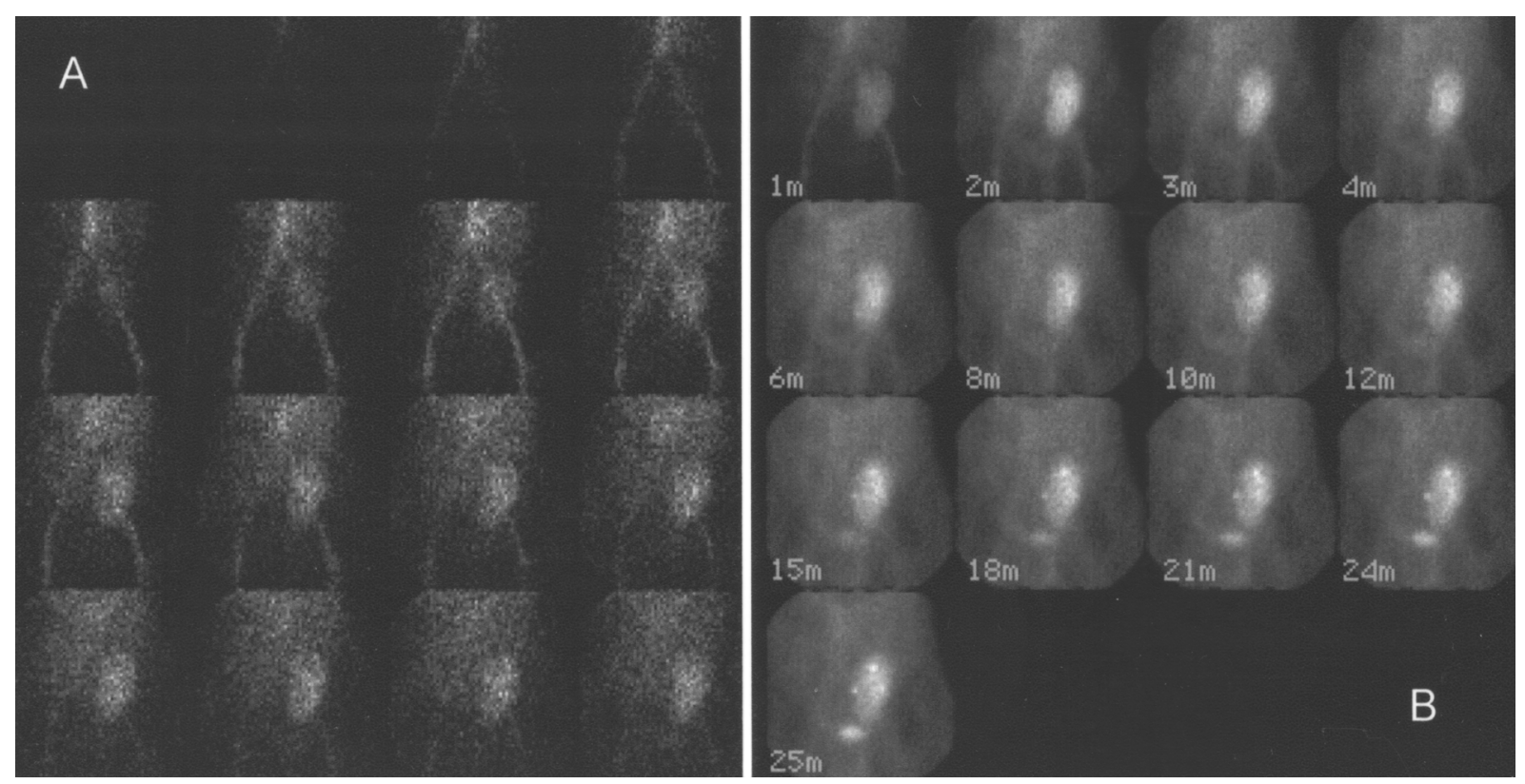

Figure 2 - Renal scintigraphic study with ${ }^{99 m}$ Tc-DTPA of a patient with acute rejection. A) Flow phase. Note the moderate reduction of the flow to the graft. B) Functional phase. There is moderately reduced accumulation, concentration and excretion of the radiotracer.

drug toxicity was also recorded. Based on these findings, the biopsies were classified as ATN, AR, $\mathrm{ATN}+\mathrm{AR}, \mathrm{CN}, \mathrm{CyT}$.

\section{Statistical Analysis}

The diagnostic value of scintigraphy was expressed as sensitivity (St), specificity (Sp), positive predictive value (PPV), negative predictive value (NPV) and accuracy (A) for the diagnosis of ATN, AR and CN. Biopsy was considered the gold standard for comparison.

\section{RESULTS}

The scintigraphic and biopsy results were compared and classified as concordant or discordant (Table-1).

Scintigraphy identified 27 ATN, 45 AR and $4 \mathrm{CN}$ events. Core biopsy identified 24 ATN, $47 \mathrm{AR}$, $4 \mathrm{CN}$ and $1 \mathrm{CyT}$ events. Table- 2 shows that 66 diagnoses (87\%) were concordant and $10(13 \%)$ were discordant (Figure-4).

Among the 10 discordant studies, in 6 scintigraphy failed to demonstrate AR detected by biopsy. In 4 cases, DTPA- ${ }^{99 m}$ Tc scintigraphy was interpreted as AR but biopsy showed only ATN in 3 cases and CyT in the remainder.

Sensitivity, specificity, positive predictive value, negative predictive value and accuracy of DTPA- ${ }^{99 \mathrm{~m}} \mathrm{Tc}$ scintigraphy for the diagnosis of ATN, $\mathrm{AR}$ and $\mathrm{CN}$ are displayed in Table-3. The overall accuracy of scintigraphy for the most important and severe complications was high $(87 \%$ for AR, $95 \%$ for ATN and $100 \%$ for $\mathrm{CN}$ ) with good specificity (86\% for AR, $89 \%$ for ATN and $100 \%$ for $\mathrm{CN}$ ).

\section{DISCUSSION}

Acute or chronic rejection is a main concern in the follow-up of transplanted patients since it can lead to graft dysfunction and loss. Most methods used in the evaluation of graft complications are aimed at the early diagnosis of rejection. The most frequently available non-invasive methods are serial serum creatinine levels, creatinine clearance, ultrasound (with or without Doppler scanning), renal scintigraphy (mainly with ${ }^{99 \mathrm{~m}} \mathrm{Tc}-\mathrm{DTPA}$ and ${ }^{99 \mathrm{~m}} \mathrm{Tc}-\mathrm{MAG}_{3}$ ), magnetic resonance imaging, urinary cytology, and serum and immunologic markers. Invasive procedures include 


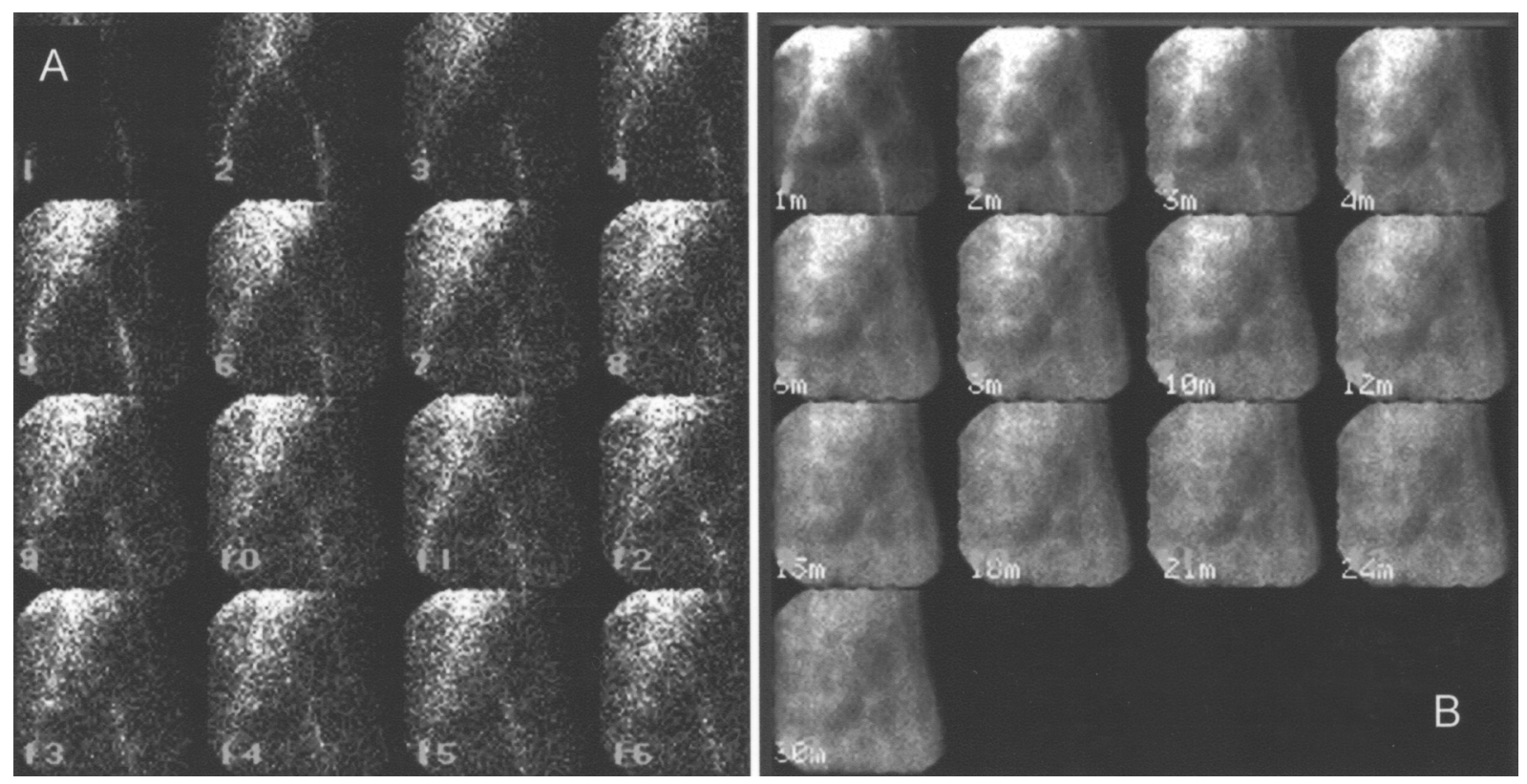

Figures 3 - Renal scintigraphic study with ${ }^{99 m} T c-D T P A$ of a patient with cortical necrosis. A) Flow phase. Note absence of flow to the graft, located in the left iliac fossa. B) Functional phase. There is no accumulation or concentration of the radiotracer in the graft. This indicates a complete functional loss of the graft.

intrarenal manometry, fine-needle aspiration biopsy (FNAB) and core biopsy, considered the definitive procedure for precise characterization of graft complications.

Accurate non-invasive diagnostic methods at a lower cost are the preferred techniques to be used. Delaney et al. (14) compared FNAB, Doppler ultrasound and radionuclide scintigraphy for the detection of renal graft complications and also performed a cost analysis. Scintigraphy was the most sensitive method for detection of acute rejection (70\% overall), while FNAB and Doppler ultrasound had sensitivities as low as $52 \%$ and $43 \%$, respectively. The cost of radionuclide scintigraphy was not considered ideal (only 9\% lower than core biopsy). In their study, FNAB not only had a low sensitivity, but also was insufficient for diagnosis of renal graft complications in approximately $13 \%$ of cases.

Hall et al. (15) also compared radionuclide scintigraphy and ultrasound without Doppler to biopsy findings, including the severity of cell infiltration. When performed within 48 hours of biopsy with heavy mononuclear interstitial cell

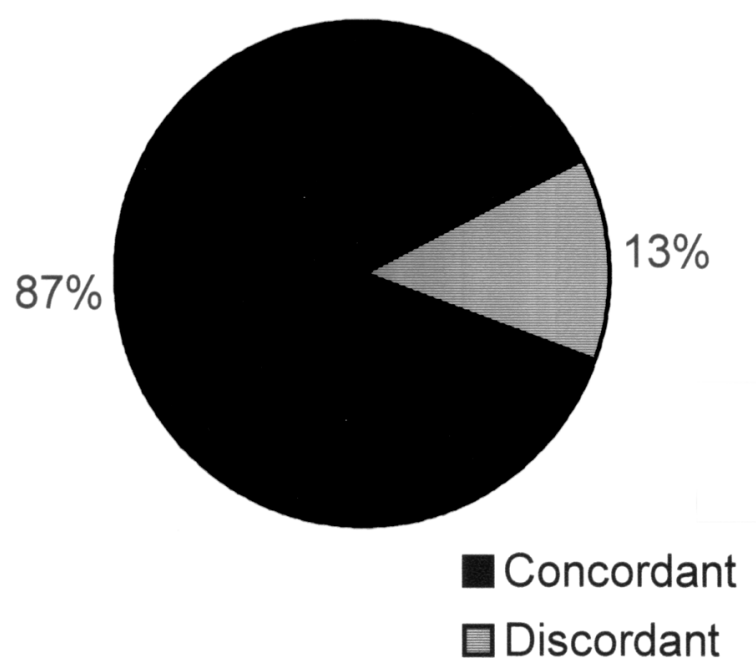

Figure 4-Correlation between scintigraphy and biopsy results. 
Table 1 - General data.

\begin{tabular}{|c|c|c|c|c|c|c|}
\hline $\mathbf{P t}$ & Age(yrs) & TT (days) & $\Delta t$ (days) & Scintigraphic Findings & BIOPSY & Analysis \\
\hline 1 & 25 & $8 d$ & 0 & AR & $\mathrm{AR}$ & $\mathrm{C}$ \\
\hline 2 & 44 & 7 & 2 & $\mathrm{ATN}+\mathrm{AR}$ & $\mathrm{ATN}+\mathrm{AR}$ & $\mathrm{C}$ \\
\hline 3 & 25 & 2 & 4 & $\mathrm{ATN}+\mathrm{AR}$ & $\mathrm{ATN}+\mathrm{AR}$ & $\mathrm{C}$ \\
\hline 4 & 24 & 9 & 0 & $\mathrm{ATN}+\mathrm{AR}$ & $\mathrm{ATN}+\mathrm{AR}$ & $\mathrm{C}$ \\
\hline 5 & 36 & 30 & 3 & ATN & ATN & $\mathrm{C}$ \\
\hline \multirow[t]{2}{*}{6} & 28 & 6 & 2 & $\mathrm{AR}$ & $\mathrm{AR}$ & $\mathrm{C}$ \\
\hline & & 19 & 3 & $\mathrm{AR}$ & $\mathrm{AR}$ & $\mathrm{C}$ \\
\hline 7 & 45 & 5 & 1 & ATN & ATN & $\mathrm{C}$ \\
\hline 8 & 55 & 1 & 5 & ATN & ATN & $\mathrm{C}$ \\
\hline 9 & 29 & 5 & 5 & ATN & ATN & $\mathrm{C}$ \\
\hline 10 & 18 & 7 & 0 & ATN & ATN & $\mathrm{C}$ \\
\hline 11 & 28 & 12 & 1 & ATN & ATN & $\mathrm{C}$ \\
\hline 12 & 46 & 4 & 3 & ATN & ATN & $\mathrm{C}$ \\
\hline 13 & 23 & 8 & 2 & $\mathrm{ATN}+\mathrm{AR}$ & $\mathrm{ATN}+\mathrm{AR}$ & $\mathrm{C}$ \\
\hline \multirow[t]{2}{*}{14} & 44 & 9 & 1 & ATN & ATN & $\mathrm{C}$ \\
\hline & & 31 & 5 & $\mathrm{AR}$ & $\mathrm{AR}$ & $\mathrm{C}$ \\
\hline \multirow[t]{4}{*}{15} & 25 & 7 & 4 & ATN & ATN & $\mathrm{C}$ \\
\hline & & 28 & 5 & ATN & ATN & $\mathrm{C}$ \\
\hline & & 42 & 0 & $\mathrm{ATN}+\mathrm{AR}$ & $\mathrm{ATN}+\mathrm{AR}$ & $\mathrm{C}$ \\
\hline & & 55 & 5 & $\mathrm{ATN}+\mathrm{AR}$ & $\mathrm{ATN}+\mathrm{AR}$ & $\mathrm{C}$ \\
\hline 16 & 30 & 13 & 1 & ATN & ATN & $\mathrm{C}$ \\
\hline 17 & 28 & 10 & 1 & $\mathrm{AR}$ & AR & $\mathrm{C}$ \\
\hline \multirow[t]{2}{*}{18} & 13 & 8 & 0 & $\mathrm{ATN}+\mathrm{AR}$ & $\mathrm{ATN}+\mathrm{AR}$ & $\mathrm{C}$ \\
\hline & & 20 & 1 & $\mathrm{AR}$ & $\mathrm{AR}$ & $\mathrm{C}$ \\
\hline \multirow[t]{2}{*}{19} & 30 & 10 & 2 & $\mathrm{ATN}+\mathrm{AR}$ & $\mathrm{ATN}+\mathrm{AR}$ & $\mathrm{C}$ \\
\hline & & 17 & 1 & $\mathrm{ATN}+\mathrm{AR}$ & $\mathrm{ATN}+\mathrm{AR}$ & $\mathrm{C}$ \\
\hline \multirow[t]{2}{*}{20} & 37 & 12 & 3 & $\mathrm{AR}$ & $\mathrm{AR}$ & $\mathrm{C}$ \\
\hline & & 23 & 2 & $\mathrm{ATN}+\mathrm{AR}$ & $\mathrm{ATN}+\mathrm{AR}$ & $\mathrm{C}$ \\
\hline \multirow[t]{4}{*}{21} & 65 & 8 & 2 & $\mathrm{ATN}+\mathrm{AR}$ & $\mathrm{ATN}+\mathrm{AR}$ & $\mathrm{C}$ \\
\hline & & 19 & 3 & $\mathrm{AR}$ & $\mathrm{AR}$ & $\mathrm{C}$ \\
\hline & & 33 & 5 & $\mathrm{AR}$ & $\mathrm{AR}$ & $\mathrm{C}$ \\
\hline & & 49 & 5 & $\mathrm{AR}$ & CyT & $\mathrm{D}$ \\
\hline 22 & 35 & 6 & 0 & ATN & $\mathrm{ATN}+\mathrm{AR}$ & $\mathrm{D}$ \\
\hline 23 & 30 & 9 & 2 & $\mathrm{ATN}+\mathrm{AR}$ & $\mathrm{ATN}+\mathrm{AR}$ & $\mathrm{C}$ \\
\hline 24 & 44 & 2 & 5 & ATN & ATN & $\mathrm{C}$ \\
\hline \multirow[t]{2}{*}{25} & 30 & 30 & 2 & $\mathrm{ATN}+\mathrm{AR}$ & $\mathrm{ATN}+\mathrm{AR}$ & $\mathrm{C}$ \\
\hline & & 36 & 0 & ATN & ATN & $\mathrm{C}$ \\
\hline 26 & 25 & 1 & 4 & ATN & $\mathrm{ATN}+\mathrm{AR}$ & $\mathrm{D}$ \\
\hline \multirow[t]{3}{*}{27} & 40 & 1 & 5 & ATN & $\mathrm{AR}$ & $\mathrm{D}$ \\
\hline & & 23 & 5 & $\mathrm{AR}$ & ATN & $\mathrm{D}$ \\
\hline & & 150 & 0 & ATN & ATN & $\mathrm{C}$ \\
\hline 28 & 38 & 2 & 4 & ATN & ATN & $\mathrm{C}$ \\
\hline 29 & 38 & 17 & 5 & ATN & ATN & $\mathrm{C}$ \\
\hline 30 & 41 & 4 & 4 & $\mathrm{ATN}+\mathrm{AR}$ & $\mathrm{ATN}+\mathrm{AR}$ & $\mathrm{C}$ \\
\hline
\end{tabular}


Table 1 - General data. (- continued)

\begin{tabular}{|c|c|c|c|c|c|c|}
\hline $\mathbf{P t}$ & $\operatorname{Age}(y r s)$ & TT (days) & $\Delta \mathrm{t}$ (days) & Scintigraphic Findings & BIOPSY & Analysis \\
\hline 31 & 20 & 43 & 2 & $\mathrm{AR}$ & $\mathrm{AR}$ & $\mathrm{C}$ \\
\hline 32 & 31 & 7 & 3 & ATN & ATN & C \\
\hline 33 & 50 & 6 & 5 & ATN & ATN & $\mathrm{C}$ \\
\hline \multirow[t]{2}{*}{34} & 47 & 13 & 1 & $\mathrm{AR}$ & AR & $\mathrm{C}$ \\
\hline & & 20 & 1 & AR & $\mathrm{AR}$ & $\mathrm{C}$ \\
\hline \multirow[t]{2}{*}{35} & 18 & 4 & 2 & ATN & $\mathrm{ATN}+\mathrm{AR}$ & $\mathrm{D}$ \\
\hline & & 120 & 2 & ATN & ATN & $\mathrm{C}$ \\
\hline 36 & 37 & 12 & 0 & $\mathrm{CN}$ & $\mathrm{CN}$ & $\mathrm{C}$ \\
\hline \multirow[t]{3}{*}{37} & 46 & 10 & 1 & ATN & ATN & $\mathrm{C}$ \\
\hline & & 32 & 3 & $\mathrm{AR}$ & $\mathrm{AR}$ & $\mathrm{C}$ \\
\hline & & 44 & 1 & $\mathrm{AR}$ & $\mathrm{AR}$ & $\mathrm{C}$ \\
\hline 38 & 29 & 5 & 2 & $\mathrm{ATN}+\mathrm{AR}$ & $\mathrm{ATN}+\mathrm{AR}$ & $\mathrm{C}$ \\
\hline 39 & 14 & 29 & 0 & $\mathrm{AR}$ & $\mathrm{AR}$ & $\mathrm{C}$ \\
\hline 40 & 14 & 32 & 2 & ATN & $\mathrm{AR}$ & $\mathrm{D}$ \\
\hline \multirow[t]{2}{*}{41} & 47 & 7 & 1 & $\mathrm{ATN}+\mathrm{AR}$ & $\mathrm{ATN}+\mathrm{AR}$ & $\mathrm{C}$ \\
\hline & & 14 & 2 & $\mathrm{ATN}+\mathrm{AR}$ & $\mathrm{ATN}+\mathrm{AR}$ & $\mathrm{C}$ \\
\hline 42 & 39 & 5 & 2 & $\mathrm{ATN}+\mathrm{AR}$ & $\mathrm{ATN}+\mathrm{AR}$ & $\mathrm{C}$ \\
\hline \multirow[t]{2}{*}{43} & 23 & 10 & 5 & $\mathrm{AR}$ & $\mathrm{AR}$ & $\mathrm{C}$ \\
\hline & & 16 & 1 & ATN & $\mathrm{AR}$ & $\mathrm{D}$ \\
\hline \multirow[t]{2}{*}{44} & 24 & 7 & 0 & $\mathrm{ATN}+\mathrm{AR}$ & $\mathrm{ATN}+\mathrm{AR}$ & $\mathrm{C}$ \\
\hline & & 14 & 0 & $\mathrm{ATN}+\mathrm{AR}$ & $\mathrm{ATN}+\mathrm{AR}$ & $\mathrm{C}$ \\
\hline 45 & 29 & 13 & 4 & $\mathrm{ATN}+\mathrm{AR}$ & $\mathrm{ATN}+\mathrm{AR}$ & $\mathrm{C}$ \\
\hline 46 & 26 & 5 & 0 & $\mathrm{CN}$ & $\mathrm{CN}$ & $\mathrm{C}$ \\
\hline 47 & 20 & 8 & 1 & $\mathrm{ATN}+\mathrm{AR}$ & $\mathrm{ATN}+\mathrm{AR}$ & $\mathrm{C}$ \\
\hline 48 & 6 & 28 & 0 & $\mathrm{AR}$ & $\mathrm{AR}$ & $\mathrm{C}$ \\
\hline 49 & 26 & 41 & 0 & $\mathrm{ATN}+\mathrm{AR}$ & $\mathrm{ATN}+\mathrm{AR}$ & $\mathrm{C}$ \\
\hline 50 & 51 & 32 & 5 & ATN & ATN & $\mathrm{C}$ \\
\hline 51 & 59 & 11 & 1 & $\mathrm{CN}$ & $\mathrm{CN}$ & $\mathrm{C}$ \\
\hline 52 & 33 & 15 & 4 & $\mathrm{AR}$ & $\mathrm{AR}$ & $\mathrm{C}$ \\
\hline 53 & 52 & 12 & 0 & $\mathrm{ATN}+\mathrm{AR}$ & ATN & $\mathrm{D}$ \\
\hline 54 & 35 & 9 & 3 & $\mathrm{CN}$ & $\mathrm{CN}$ & $\mathrm{C}$ \\
\hline 55 & 13 & 32 & 4 & $\mathrm{ATN}+\mathrm{AR}$ & ATN & $\mathrm{D}$ \\
\hline
\end{tabular}

$P t=$ patient $; T T=$ time after kidney transplant; $\Delta t=$ time between scintigraphy and biopsy; $C=$ Concordant; $D=$ Discordant; $A T N=$ acute tubular necrosis; $A R=$ acute rejection; $C y T=$ cyclosporine nephrotoxicity; $C N=$ cortical necrosis .

infiltration, radionuclide scintigraphy had a sensitivity of $96 \%$ for the detection of acute rejection while the sensitivity of ultrasound was only $21 \%$. Nevertheless, the specificity of scintigraphy was low, $54 \%$. Sensitivity of radionuclide scintigraphy was low in cases with mild or no interstitial cell infiltration, but was still better than that of ultrasound (6/13 patients versus $0 / 4$ patients, respectively). The radionuclide scintigraphy study frequently contributed to the final diagnosis particularly when the biopsy findings were inconclusive or the patient responded to therapy, consistent with the radionuclide scintigraphy findings. Consequently, the final diagnosis was not always "independent" of the radionuclide scintigraphy 
Table 2 - Correlation of the most frequent findings of scintigraphy and biopsy.

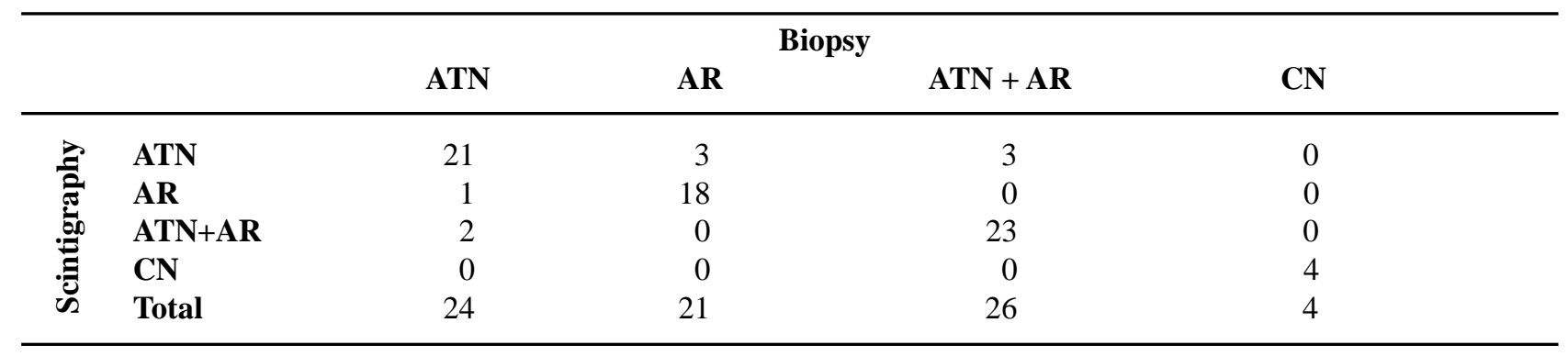

$A T N=$ acute tubular necrosis; $A R=$ acute rejection; $C N=$ cortical necrosis .

results. In their experience, a biopsy finding with heavy cellular infiltration was the most reliable independent factor for the diagnosis of acute rejection.

Akhtar et al. (16) also reported low sensitivity and specificity of ultrasound and Doppler ultrasound. They found that an increase in the resistivity index greater than 0.7 was present in $31.5 \%$ of AR but was also elevated in $26.7 \%$ of CyT and in $44.4 \%$ of ATN. Aktas et al. (17) reported Doppler ultrasound sensitivities as low as $45 \%$ for low-grade rejections (based on Banff criteria) and as high as $88 \%$ for highgrade rejections. Surprisingly, the same sensitivities were found for radionuclide scintigraphy when altered perfusion alone was considered. When the analysis included also altered concentration and retention of the radiopharmaceutical, sensitivity of scintigraphy increased to $64 \%$ and $100 \%$ for low and high grade rejection, respectively, which is still lower than in other reports.

Table 3 - Diagnostic value of scintigraphy.

\begin{tabular}{llll}
\hline & ATN & AR & CN \\
\hline Sensitivity & $98 \%$ & $87 \%$ & $100 \%$ \\
Specificity & $89 \%$ & $86 \%$ & $100 \%$ \\
PPV & $94 \%$ & $91 \%$ & $100 \%$ \\
NPV & $96 \%$ & $81 \%$ & $100 \%$ \\
Accuracy & $95 \%$ & $87 \%$ & $100 \%$ \\
\hline
\end{tabular}

$P P V=$ positive predictive value; $N P V=$ negative predictive value; $A T N=$ acute tubular necrosis; $A R=$ acute rejection; CN = cortical necrosis.
The most frequent complications found in the present study (ATN, AR and CN) were those expected to occur in the early acute phase post transplant, when this population was analyzed (first 3 weeks after surgery).

Radionuclide scintigraphy failed to detect acute rejection in 6 of the 76 studies $(8 \%)$. On the other hand, in 3 patients in whom radionuclide scintigraphy showed AR with negative biopsies, the clinical follow-up confirmed rejection by improvement in renal function after systemic treatment with immunosuppressive drugs or new biopsies performed a few days later. False-negative biopsies can occur, since the fragment removed may not always be representative of the entire histopathological process and AR most commonly happens in multiple focal areas. The overall accuracy of core biopsy has been reported to be about $91 \%$ $(18,19)$.

If the false-positive cases of AR were compared to clinical outcome instead of biopsy results, the specificity and accuracy of radionuclide scintigraphy for the diagnosis of AR in the current study would increase to $96 \%$ and $91 \%$, respectively.

Detection of ATN was also efficient in the present group of patients (98\%), coupled with a specificity of $95 \%$. Cófan et al. (20) assessed the value of dynamic radionuclide scintigraphy for the detection of ATN with ${ }^{99 m} \mathrm{Tc}-\mathrm{MAG}_{3}$ compared to Doppler ultrasound in 45 patients with ATN. The authors concluded that Doppler ultrasound does not discriminate the ATN severity and a resistivity index $=1$ in the baseline study could not be related to a 
worse prognosis. Nevertheless, severe ATN was associated with prolonged dialysis treatment and reduced graft survival.

Although the number of cortical necrosis events was small (4 cases) in the present study, the high accuracy achieved was expected to happen, since the alteration in flow and function of the graft is dramatic. In the present study there was only a single case of CyT, thus, it was not possible to estimate a reasonable value for the diagnostic accuracy of radionuclide scintigraphy for the diagnosis of this complication and CyT is typically a late complication of the transplant.

The high values of sensitivity, specificity and overall accuracy for the most frequent early graft complications in this series of renal transplants can be explained because all the patients analyzed had a previous scintigraphy study in the first 24 hours post surgery (baseline study), and also because the nuclear medicine physicians were not blind to the clinical data and that a baseline study is routinely performed, preferably in the first post operative day, for comparison.

Khajehmugehi et al. (18) concluded after reviewing 230 episodes of AR in renal transplant recipients, that although the most sensitive (91\%) way to diagnose AR was kidney biopsy, "the best mode of diagnosing rejection was DTPA isotope scanning." However, only the kidney biopsy can give the diagnosis and severity of the acute rejection, especially in cases when ATN is associated with rejection or in presence of a vascular component of rejection.

\section{CONCLUSIONS}

${ }^{99 m}$ Tc-DTPA scintigraphy is a safe, noninvasive and easy-to-perform method that has shown a good correlation with biopsy results and clinical evolution of renal transplanted patients.

We have a strong belief that the best approach in clinical practice to aid in the correct diagnosis of graft complications is to routinely perform a baseline ${ }^{99 \mathrm{~m}} \mathrm{Tc}$-DTPA study as screening, preferably in the first post transplant hours, which is useful for further comparison, improving the accuracy of this method.
Gathering all these data and using biopsy to confirm diagnosis, leads to prompt intervention when necessary.

The early detection of severe graft complications such as rejection, vascular thrombosis or graft necrosis will lead to their prompt treatment, reducing the risks of further kidney damage or of complications derived from the presence of a nonviable graft.

\section{REFERENCES}

1. Kirchner PT, Rosenthall L: Renal transplant evaluation. Semin Nucl Med. 1982; 12: 370-8.

2. Lubin E, Shapira Z, Melloul M, Youssim A: Scintigraphic detection of vascular and urological complications in the transplanted kidney: 133 cases. Eur J Nucl Med. 1985; 10: 313-6.

3. Rutland MD: A comprehensive analysis of renal DTPA studies II: Renal transplant evaluation. Nucl Med Commun. 1985; 6: 21-30.

4. Dubovsky EV, Russell CD, Bischof-Delaloye A, Bubeck B, Chaiwatanarat T, Hilson AJ, et al.: Report of the Radionuclides in Nephrourology Committee for evaluation of transplanted kidney (review of techniques). Semin Nucl Med. 1999; 29: 175-88.

5. Isiklar I, Aktas A, Uzuner O, Demirag A, Haberal M: Power Doppler ultrasonography compared with scintigraphy in the diagnosis of renal allograft dysfunction. Transplant Proc. 1999; 31: 3330-1.

6. Neimatallah MA, Dong Q, Schoenberg SO, Cho KJ, Prince MR: Magnetic resonance imaging in renal transplantation. J Magn Reson Imaging. 1999; 10: 357-68.

7. Brown ED, Chen MY, Wolfman NT, Ott DJ, Watson NE Jr.: Complications of renal transplantation: evaluation with US and radionuclide imaging. Radiographics. 2000; 20: 607-22.

8. Heaf JG, Iversen J: Uses and limitations of renal scintigraphy in renal transplantation monitoring. Eur J Nucl Med. 2000; 27: 871-9.

9. George EA, Codd JE, Newton WT, Haibach H, Donati RM: Comparative evaluation of renal transplant rejection with radioiodinated fibrinogen, ${ }^{99 \mathrm{~m}} \mathrm{Tc}$-sulfur colloid, and ${ }^{67} \mathrm{Ga}$-citrate. J Nucl Med. 1976; 17: 175-80.

10. Carmody E, Greene A, Brennan P, Donohue J, Carmody M, Keeling F: Sequential Tc-99m mercaptoacetyl-triglycine (MAG3) renography as an evaluator of early renal transplant function. Clin Transplant. 1993; 7: 245-9. 
11. Oriuchi N, Miyamoto K, Hoshino K, Imai J, Takahashi Y, Sakai S, et al.: ${ }^{99 \mathrm{~m}} \mathrm{Tc}-\mathrm{MAG} 3$ : a sensitive indicator for evaluating perfusion and rejection of renal transplants. Nucl Med Commun. 1997; 18: 400-4.

12. el Maghraby TA, van Eck-Smit BL, de Fijter JW, Pauwels EK: Quantitative scintigraphic parameters for the assessment of renal transplant patients. Eur $\mathbf{J}$ Radiol. 1998; 28: 256-69.

13. Racusen LC, Solez K, Colvin RB, Bonsib SM, Castro MC, Cavallo T, et al.: The Banff 97 working classification of renal allograft pathology. Kidney Int. 1999; 55: 713-23.

14. Delaney V, Ling BN, Campbell WG, Bourke JE, Fekete PS, O'Brien DP 3rd, et al.: Comparison of fine-needle aspiration biopsy, Doppler ultrasound, and radionuclide scintigraphy in the diagnosis of acute allograft dysfunction in renal transplant recipients: sensitivity, specificity, and cost analysis. Nephron. 1993; 63: 263-72.

15. Hall JT, Kim EE, Pjura GA, Maklad NF, Sandler CM, Verani R: Correlation of radionuclide and ultrasound studies with biopsy findings for diagnosis of renal transplant rejection. Urology. 1988; 32: 172-9.
16. Akhtar F, Rana TA, Kazi J, Zafar N, Hashmi A, Bhatti $S$, et al.: Correlation between biopsies and noninvasive assessment of acute graft dysfunction. Transplant Proc. 1998; 30: 3069.

17. Aktas A, Isiklar I, Gulaldi NC, Dermirag A, Demirhan B: Sensitivity of radionuclide imaging, Doppler, and gray-scale ultrasound to detect acute rejection episodes, based on the pathologic grade of acute rejection. Transplant Proc.1998; 30: 786-7.

18. Khajehmugehi AR, Mehrsai AR, Taheri M, Khan ZH: Evaluation of acute kidney rejection in 230 renal transplant recipients. Transplant Proc. 1998; 30: 7301.

19. Hughes D: Fine-Needle Aspiration Cytology of the Transplanted Kidney, In: Morris PJ (ed.). Kidney Transplantation. $5^{\text {th }}$ Ed. Philadelphia, PA, WB Saunders. 2001, 392-407.

20. Cófan F, Gilabert R, Oppenheimer F, Bru C, Lomena F, Setoain F, et al.: Dupplex-Doppler ultrasound and MAG-3 scintigraphy in the evaluation of acute tubular necrosis after kidney transplantation. Transplant Proc. 1997; 29: 1376-7.
Received: July 21, 2003 Accepted after revision: November 14, 2003

\section{Correspondence address:}

Dr. Elba C.S.C. Etchebehere

Serviço de Medicina Nuclear, Depart Radiologia

Hospital das Clínicas da UNICAMP

Caixa Postal 6142, Campinas, 13081-970, Brazil

Fax: + 5519 3251-1041

E-mail: elba@mn-d.com 